\title{
МАРКЕТИНГОВІ СТРАТЕГІЇ СОЦІАЛЬНО-ЕКОНОМІЧНОГО РОЗВИТКУ РЕГІОНІВ УКРАЇНИ
}

\section{МАРКЕТИНГОВЫЕ СТРАТЕГИИ СОЦИАЛЬНО-ЭКНОМИЧЕСКОГО РАЗВИТИЯ РЕГИОНОВ УКРАИНЫ}

\section{THE MARKETING STRATEGY OF SOCIO-ECONOMIC DEVELOPMENT OF UKRAINE'S REGIONS}

У статті розглянуто напрями реалізачії проектів стратегічного економічного розвитку регіонів Украйни в умовах самоврядування з урахуванням необхідності підвищення ролі реального сектора економіки.

За допомогою маркетингових підходів визначено основні напрямки соціальноекономічної діяльності в регіонах України, із застосуванням маркетингових досліджень здійснено аналіз поточної ситуації та порівняння відповідних показників між собою, виокремлено чинники, які мають вплив на пріоритетний подальший розвиток регіонів, сформульовано пропозищіі використання інструментів комплексу маркетингу для досягнення поставлених иілей. Поставлено питання необхідності наукового та кадрового забезпечення основних галузей регіону.

Запропоновано перспективні иляхи самостійного сочіально-економічного розвитку областей, зокрема за допомогою стратегічного партнерства, створення кластерів, вдосконалення роботи технологічних парків та дослідницьких иеентрів.

Ключові слова: регіональна економіка, управління регіоном, стратегічне партнерство, кластер, маркетинг регіону, маркетинг партнерських стосунків.

В статье рассмотрень направления реализачии проектов стратегического економического развития регионов Украинь в условиях самоуправления с учётом необходимости повышения роли реального сектора экономики.

С помощью маркетинговых подходов определень основные направления сочиальноэкономической деятельности в регионах Украины, с использованием маркетинговых исследований осуществлён анализ текущей ситуаџии и сравнение соответствуюших показателей между собой, выделены факторы, имеющие влияние на приоритетное дальнейтее разитие регионов, сформулированы предложения использования инструментов комплекса маркетинга для достижения поставленных ичелей. Поставлен вопрос необходимости научного и кадрового обеспечения основных отраслей региона.

Предложены перспективные пути самостоятельного соииально-экономического развития областей, в частности с помощью стратегического партнёрства, создания кластеров, совершенствования работы технологических парков и исследовательских иентров. 
Ключевые слова: региональная экономика, управление регионом, стратегическое партнёрство, кластер, маркетинг региона, маркетинг партнёрских отношений.

In article the directions of the strategic economic development projects realization of Ukraine's regions of conditions in view of increase necessity role of real economics sector.

With the marketing's help approaches the basic socio-economic activity directions in Ukraine's regions are determined, with marketing researches use the analysis of the current situation and comparison of the appropriate parameters among themselves is carried out, the factors having influence on a priority distant neck development of regions are allocated the offers of the marketing's complex tools use for achievement of object in views are formulated. The question of scientific and personnel maintenance necessity of the region's basic branches is put.

The perspective ways independed socio-economic of areas development, in particular with the help of strategic partnership, creation cluster, perfection of technological parks work and research centres are offered.

Keywords: regional economy, management by region, strategic partnership, cluster, marketing of region, partnership marketing relations.

Вступ. Сьогоденний економічний стан України надважкий. Наша держава має необхідність реагувати не тільки на економічні, а й на політичні та соціальні виклики, поставлені перед нею останніми подіями зовнішнього та внутрішнього середовища. Останні двадцять років у країні руйнувався реальний сектор економіки на догоду розвитку невиробничої сфери (послуги, фінанси, реклама тощо). В умовах глобалізації прорив на світові ринки можуть забезпечити не окремі проект чи галузь, а лише міжгалузеві комплекси, основою яких $є$ виробництво промислових товарів 3 технологічними інноваціями, що застосовуються як безпосередньо в промисловості, так і в сільському господарстві. В Україні перспектива впливу на економічні взаємовідносини проявляється в необхідності створення замкнутих систем довготривалих зв'язків 3 постачальниками сировини, виробниками, посередниками та споживачами, що одержали назву кластеризації економіки з включенням у процес регіональних науководослідницьких центрів, вдосконалення або відновлення роботи технопарків тощо. Останнім часом у цих напрямках проведено наукові узагальнення за участю Я. Гордона [1], О. Амоші, 3. Варналія [2], В. Геєца, В. Герасимчука, Б. Данілішина, Н. Куденко, А. Мазура [3], С. Шкарлета та деяких інших.

Постановка завдання. Метою статті $є$ з'ясування напрямів перспектив стратегічного розвитку регіонів в умовах підвищення ролі та прав місцевого самоврядування областей України.

Методологія. У роботі застосовано загальнотеоретичні методи (системного підходу, аналізу поточної ситуації, порівняння економічних показників між собою, узагальнення фундаментальних та прикладних показників поточної ситуації регіону) та методи маркетингових досліджень, за допомогою яких визначено основні сфери діяльності, виокремлено чинники, 
які мають вплив на подальший розвиток пріоритетних напрямів, та сформульовано пропозиції інструментів, за допомогою яких можна досягти поставлених перед громадою регіонів цілей.

Результати дослідження. На сьогодні у більшості регіонів України гіпертрофовано паразитичний сектор послуг на збиток реальному виробничому сектору економіки та на користь економічно розвинутих країн, які й формують левову частку сукупного світового попиту, табл.1. Розмір реального сектора США вчетверо менше сектора сфери послуг, а реального сектора СС - втричі. В Україні ж сфера послуг перевищує розмір реального сектора ВВП на 40\%, хоч на сьогодні це мало що змінює у кращий бік. Тим більше в українській ситуації, якщо справа піде за спільним з СС сценарієм, зберегти реальний сектор на сьогоденному рівні через значну втрату російського ринку та ринків деяких інших країн буде неможливо.

Таблиця 1

ВВП України за умов вступу до Свросоюзу

\begin{tabular}{|c|c|c|c|c|}
\hline $\begin{array}{l}\text { Найменування } \\
\text { економічних } \\
\text { показників }\end{array}$ & $\begin{array}{l}\text { Загальний } \\
\text { ВВП, } \\
\text { млрд. дол. }\end{array}$ & $\begin{array}{c}\text { Ефемерний } \\
\text { ВВП } \\
\text { (послуги), } \\
\text { млрд. дол. }\end{array}$ & $\begin{array}{c}\text { ВВП в реальному } \\
\text { секторі економіки } \\
\text { (промисловість, сільське } \\
\text { господарство), млрд. дол. }\end{array}$ & $\begin{array}{l}\text { Державний } \\
\text { борг, } \\
\text { млрд. дол. }\end{array}$ \\
\hline $\begin{array}{l}\text { Структура ВВП } \\
\text { України, } 2012 \text { р.* }\end{array}$ & 176 & 103 & 74 & 64 \\
\hline $\begin{array}{l}\text { Структура ВВП СС, } \\
2012 \text { p. }\end{array}$ & 16360 & 12008 & 4335 & 15500 \\
\hline $\begin{array}{l}\text { Структура ВВП } \\
\text { США, } 2012 \text { р. }\end{array}$ & 15680 & 12497 & 3183 & 17084 \\
\hline $\begin{array}{l}\text { Гіпотетичний ВВП } \\
\text { України після } \\
\text { проходження } \\
\text { структурної кризи за } \\
\text { умов вступу в } \\
\text { Свросоюз }(2018 \text { р)** }\end{array}$ & 99 & 40 & 54 & 39 \\
\hline
\end{tabular}

* - разрахунок зроблено за перший після світової економічної (2008-2011рр.) кризи рік, який одночасно був і останнім докризовим в Україні роком;

** - коли здійснювався разрахунок, ще не було інформації з адміністрації Президента України, що вступ до Євросоюзу планується вже на 2020 рік.

На сьогодні однією з основних проблем регіонів є монотонне зменшення робочих місць на крупних i середніх підприємствах та неможливість їх поповнення за рахунок невеликого збільшення працівників на дрібних підприємствах та у сфері обслуговування. Як наслідок, чисельність зайнятого населення у таких визначальних для України галузях економіки, як 
промисловість та будівництво, значно зменшилась протягом останніх років, табл. 2 [4]. Тут особливо турбує зайнятість населення у промисловості, яка на 2010 рік практично співпадає з кількістю необхідних у майбутньому фахівців цієї сфери діяльності (відповідно 49\% та 48\% до рівня 1990 року). Найближчим часом зайнятість у цих сферах значним чином не зміниться, оскільки навчальні заклади I-II рівнів сьогодні випускають ще менше фахівців технічних спеціальностей ( 91,2 тис. чол. у 2014 році) [5], які є основою будьякого промислового виробництва, адже, як правило, саме з них формуються кваліфіковані робітники та керівники нижньої ланки — “майстри цехів” та “майстри дільниць”.

Таблиця 2

Кількість зайнятого населення за видами діяльності, млн. чол.

\begin{tabular}{|c|l|c|c|c|c|c|c|}
\hline \multirow{2}{*}{$\begin{array}{c}\text { Ном. } \\
\text { пор. }\end{array}$} & \multicolumn{1}{|c|}{ Основні галузі економіки } & \multicolumn{5}{|c|}{ Період, що розглядається } \\
\cline { 3 - 8 } & & 1990 & 1995 & 2000 & 2005 & 2010 & $\begin{array}{c}2010 \\
\text { до } \\
1990\end{array}$ \\
\hline 1 & Сільське і лісне господарство & 2,82 & 1,99 & 4,33 & 3,97 & 3,09 & 1,10 \\
\hline 2 & Промисловість & 7,10 & 5,04 & 4,60 & 4,07 & 3,46 & 0,49 \\
\hline 3 & Будівництво, транспорт і зв'язок & 3,41 & 2,24 & 2,26 & 2,34 & 2,33 & 0,68 \\
\hline 4 & Торгівля, діяльність ресторанів і готелів & 2,09 & 1,50 & 3,12 & 418 & 4,83 & 2,32 \\
\hline 5 & Фінансова діяльність та операції з нерухомістю & 0,46 & 0,53 & 0,98 & 1,21 & 1,49 & 3,22 \\
\hline 6 & $\begin{array}{l}\text { Державне управління, освіта, охорона } \\
\text { здоров'я }\end{array}$ & 3,38 & 3,45 & 4,19 & 4,05 & 4,25 & 1,26 \\
\hline 7 & Інші види економічної діяльності & 0,62 & 0,57 & 0,69 & 0,84 & 0,81 & 1,29 \\
\hline & Всього & 19,89 & 15,33 & 20,18 & 20,68 & 20,27 & 1,02 \\
\hline 8 & $\begin{array}{l}\text { Випущено фахівців закладів І-ІІ рівня } \\
\text { акредитації }\end{array}$ & 0,23 & 0,19 & 0,15 & 0,14 & 0,11 & 0,48 \\
\hline
\end{tabular}

На першому етапі необхідне розроблення проектів, що включають постійне вдосконалення (створення, коректування та ін.) комплексів маркетингу на основі проведення відповідних маркетингових досліджень. Це допоможе, по-перше, використати економічні кластери - складні форми коопераційної взаємодії на регіональному рівні, які дають можливість розробити обгрунтовані стратегії формування відповідних наукововиробничих, науково-сільськогосподарських, оздоровчих та спортивних об'єднань й відповідно до цього стимулювати подальший розвиток нового типу ринкових стосунків; по-друге, створити реальні, а не ілюзорні регіональні науково-промислові комплекси (технопарки) із залученням ВНЗ та інших наукових і проектних установ області [6], що, окрім основних функцій, 
має зменшити відтік молодих фахівців після закінчення навчання за межі регіону; по-третє, застосувати концепцію маркетингу партнерських стосунків - 5-го «Р» комплексу маркетингу як на рівні районів і міжрайонних об'єднань, що стосується більшості сфер економічної діяльності окремої області, так і суміжних районів кількох областей.

Можна виділити кілька основних напрямів реалізації проектів. У промисловості це: 1) створення групи фахівців під технічним керівництвом обласного управління економіки із реальним залученням науковців, бізнесменів та ін. 3 метою розробки короткострокової (до 2016 р.) та середньострокової (до 2020 р.) маркетингової програми сталого розвитку області на наявній ресурсній базі; 2) організація регіонального науковопромислового комплексу (технопарку) із профільного управління (відділу) обласної державної адміністрації, установи інфраструктури підтримки (транспортні, побутові, спеціалізовані комунальні утворення) на базі існуючих підприємств за участю вищих навчальних закладів, наукових і проектних організацій, (рисунок), [7]; 3) створення на базі університетів, науководослідних інститутів та інших наукових установ мережі закладів венчурного бізнесу, інжсиірингових фірм, що мають довести розробки науковців до придатного для комерційного використання вигляду; 4) всілякий розвиток маркетингу партнерських стосунків у системі постачальник сировини $\rightarrow$ виробник $\rightarrow$ посередник $\rightarrow$ споживач між підприємствами, фірмами, установами регіону. 


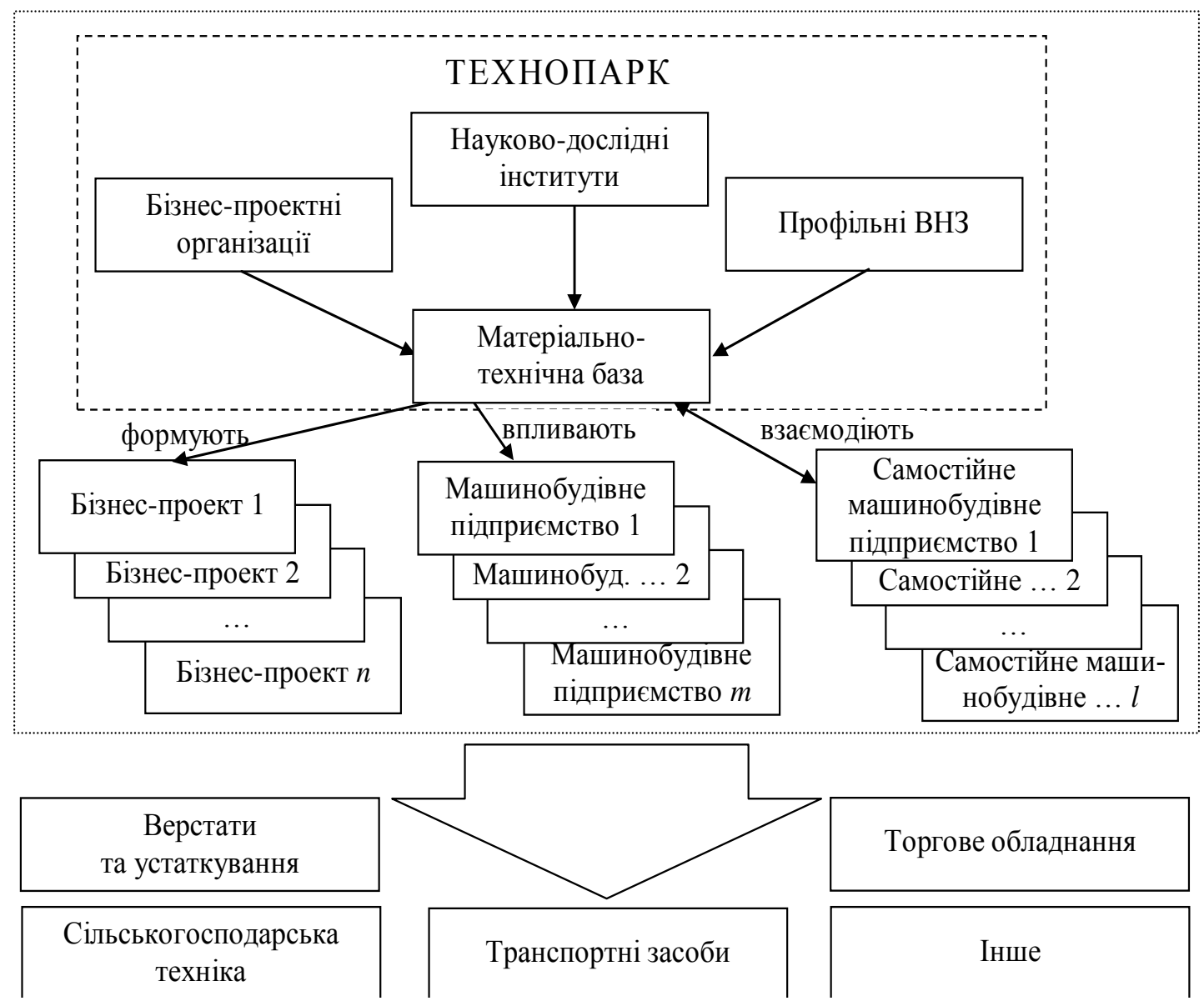

Рисунок. Схема функціонування комплексного технопарку в регіоні

У табл. 3 наведено напрямки інноваційного розвитку на регіональному, національному та міжнародному рівнях.

Таблиця 3

\section{Пріоритетні напрямки інноваційного розвитку країни}

Рівні ієрархічної інтеграції

Регіональний

Створення максимально повного виробничого циклу

Розвиток власної

Загальнона- фундаментальної та

Зміст складових інноваційного розвитку

Максимально повне забезпечення свого населення власним продовольством

Забезпечення сировинної та
Удосконалення власної системи кредитування й внутрішньої торгівлі з обмеженням іноземної присутності Забезпечення боєздатності власної 


\begin{tabular}{|c|c|c|c|}
\hline ціональний & прикладної науки & $\begin{array}{l}\text { енергетичної } \\
\text { незалежності }\end{array}$ & $\begin{array}{l}\text { армії, авіації та } \\
\text { військового флоту }\end{array}$ \\
\hline Міжнародний & $\begin{array}{l}\text { Розробка, конструювання } \\
\text { та функціонування } \\
\text { торговельного флоту і } \\
\text { пасажирського } \\
\text { авіатранспорту }\end{array}$ & $\begin{array}{l}\text { Функціонування } \\
\text { космічної програми }\end{array}$ & $\begin{array}{l}\text { Функціонування } \\
\text { ядерної програми, у } \\
\text { тому числі військової }\end{array}$ \\
\hline
\end{tabular}

Таким чином, реальний сектор економіки, що реалізується елементом комплексу маркетингу product, вже через п'ять років може превалювати над сектором сфери послуг. Якщо промисловий сектор збільшуватиметься, то зменшаться й корупція та інші злочини, бо додатковий прибуток, що народжується за результатами багатьох виробничих переділів і одержується за рахунок продажу технічно складної продукції, набагато важче вивезти в офшори, ніж, наприклад, банківський чи рекламний. Головна перевага орієнтації на реальний сектор економіки полягає в тому, що держава виходитиме $з$ кризи активно, розвиваючи власну індустрію, а не пасивно спостерігаючи, як так звані «європейські ринкові регулятори» руйнують власне виробництво i, як наслідок, жорстко знижують рівень життя українців.

У сферу забезпечення побутової життєдіяльності регіону входить будівництво, ефективне використання енергоресурсів та транспорту, а також функціонування комунального господарства. Зрозуміло, що зниження зайнятості населення в цій сфері на третину говорить про різке погіршення іiі стану. Цілком природно, що в компетенції регіонального маркетингу зробити ціну на енергоносії оптимальною (відомо, що основну масу населення цікавить в основному ціна опалення помешкань). Саме тому, наприклад, $є$ не зрозумілою різниця в запропонованих на опалювальний сезон 2014-2015 років цінах на опалення одного квадратного метра житла у великих та обласних містах України: Кривий Ріг — 12,94 грн.; Кіровоград - 12,35; Суми - 11,73; Луганськ - 11,31; Донецьк - 11,22; Дніпропетровськ - 11,16; Рівне 10,83; Миколаїв - 9,94; Одеса - 9,74; Луцьк - 9,62; Харків - 9,58; Київ 9,22; Черкаси і Херсон по 9,07; Полтава - 8,83; Житомир та Ужгород по 8,40; Тернопіль - 8,12; Чернігів - 7,82, Чернівці - 7,61, Вінниця - 6,25. Львів 6,08; Івано-Франківськ - 5,69, що не має нічого спільного не тільки 3 економікою регіону, а й з економікою взагалі. Будь-який регіон має розвивати комунальний пасажирський транспорт та будувати соціальне житло. У наведеній сфері найважливішим є елемент комплексу маркетингу price. 
У соціальній сфері серед основних напрямів реалізації проектів можна виділити: 1) створення перспективного плану розвитку інфраструктури населених пунктів на основі проведення досліджень соціального маркетингу; 2) спільний розвиток мережі комунальних лікувальних, оздоровчих та санаторно-курортних закладів із відомчим, бізнесовим та приватним фінансуванням; 3) поєднання розрізнених туристичних маршрутів етнографічного, сільського, зеленого туризму із загальноукраїнськими маршрутами 3 відвідуванням історичних, культурних та архітектурних пам'яток, 3 регіональними відділеннями в найбільших містах регіону; 4) оптимальне поєднання масового та дитячого спорту із професійним; максимально ефективне використання спортивних споруд.

У сільському господарстві це: 1) кластеризація, де необхідно визначити потенціал створення економічних кластерів в окремих підгалузях АПК, націлених на розвиток замкнутого високотехнологічного агропромислового виробництва та на створення екологічно чистої конкурентоспроможної сільськогосподарської продукції: а) зернового кластера (мукомельні підприємства, спиртові заводи, зернотрейдери), б) бурякоиукрового (споживачі продуктів переробки буряку, спиртові заводи, внутрішній та зовнішній ринок цукру), в) молочного (молокопереробні підприємства, виробники сухого молока, спеціалізовані підприємства), г) кластера свинарства (м'ясокомбінати, сільгоспринки в містах обласного підпорядкування) тощо, 2) розроблення механізмів розвитку та підтримки агропромислових кластерних структур; 3) впорядкування лісового господарства в напрямку переробки відходів лісового господарства та деревообробних підприємств на екологічно чисті паливні елементи.

Зазначене вище неможливе без послідовної політики регіону в сфері вищої освіти та науки, тобто реалізації елемента маркетингу (partners). Сьогодні ті чи інші ВНЗ на місцевому чи регіональному ринку освіти більше суперники, ніж колеги. Навіть у такій необхідній щорічній перепідготовиі фахівиів за рахунок коштів обласного бюджету, зокрема за напрямками маркетингу, менеджменту, управління інноваційною діяльністю тощо, немає стратегічного регіонального підходу. Створені наприкінці 90-х років минулого століття ради ректорів так і не стали ефективними, як і багато інших прогресивних починань, а саме вони мають бути зв'язковою ланкою між вищими навчальними закладами, населенням та органами місцевого самоврядування [8]. Можливо, певною мірою мають допомогти й запропоновані в Законі України «Про вищу освіту» від 01.07.14 № 1556-VII [9] так звані наглядові ради. Але існує значне занепокоєння, що без належної 
підтримки органів управління територіями їх діяльність теж не буде ефективною. Високі вимоги сьогодні висуваються й до якісного складу науково-дослідного сектору ВН3, що має реалізовуватися елементом комплексу маркетингу (personal). Тут за допомогою маркетингового підходу потрібно визначити споживчі переваги в науковому продукті (друковані науково-дослідницькі матеріали, успіхи на всеукраїнських конкурсах студентських наукових робіт, кількість та розміри грантів, обсяги фінансування науково-дослідних тем за рахунок бюджетних коштів тощо) та врахувати готовність замовника платити за створений у технопарку на кафедрах та в лабораторіях ВНЗ або дослідницького центру науководослідного чи проектного продукту. Саме так відбувається і в університетах США, де, за останніми даними, “...29 відсотків членів професорськовикладацького складу присвячують більше 20 годин на тиждень науковій роботі" [10]. Отже, на обласному рівні необхідні: 1) введення нового механізму працевлаштування випускників на основі багатосторонніх договорів між професійно-технічними навчальними закладами, підприємствами, фірмами, установами, організаціями - замовниками робітничих кадрів та учнями; 2) формування системи своєчасної й достатньої післядипломної освіти; 3) максимально можливе наближення бюджетних наукових тематик, а також тем, виконуваних у вищій школі, та дисертаційних досліджень до потреб регіону.

Таким чином, реалізовуватиметься політика держави, націлена на підвищення самостійності регіонів у розв'язанні економічних та соціальних завдань, що як ніколи гостро постають перед Україною [11].

Висновки. На сьогодні Україна мусить реагувати на нові зовнішні та внутрішні виклики сучасності і потребує радикальних змін у соціальноекономічній територіальній політиці. Таким напрямком $\epsilon$ комплексний підхід до запровадження регіональних стратегій, що становить наукову новизну даного дослідження. Цей підхід передбачає використання маркетингу партнерських стосунків, кластеризацію, створення потужних наукових дослідницьких центрів тощо, що дасть змогу областям України, спираючись на власні інтелектуальну та економічну міць, перейти від глобальної залежності та глобальних ризиків до більш самостійного сталого розвитку. На обласному рівні необхідне введення нового механізму працевлаштування випускників, забезпечення кваліфікованої післядипломної освіти, максимальне наближення сукупності наукових тематик до потреб регіону.

Перспективою подальшого дослідження в сфері підвищення економічної самостійності регіонів $є$ розроблення конкретних організаційно-економічних 
механізмів самоврядування та їх апробація на відповідних економічних об'єктах, що дасть змогу їх ефективного застосування на практиці.

\section{Література:}

1. Гордон Ян Х. Маркетинг партнёрских отношений [пер. с англ. ; под ред. О.А. Третьяк] / Ян Х. Гордон // СПб : Питер, 2001. - 384 c.

2. Державна регіональна політика України: особливості та стратегічні пріоритети: монографія / за ред. 3.С. Варналія. - К.: НІСД, 2007. - 768 с.

3. Современные инновационные структуры и коммерциализация науки / Под ред. А.А. Мазура. - Харьков : Полиарт, 2000. - 254 с.

4. Статистичний щорічник України за 2010 рік / За ред. Осауленка О.Г. - Київ: Державна служба статистики, 2011. - 560 с.

5. Гаврилюк В. Я. Особливості розвитку та діяльності ВНЗ у глобальній економіці / В.Я. Гаврилюк // Вісник Національного університету “Львівська політехніка" : Менеджмент та підприємництво в Україні : Етапи становлення та проблеми розвитку. — Львів, НТУ “Львівська політехніка”. 2013. 一№ 769. 一 С. 405-412.

6. Тєлєтов О.С. Напрямки реалізації проектів стратегічного розвитку регіонів / О.С. Тєлєтов, М.В. Провозін // Тези доповідей X Міжнародної науково-практичної конференції «Маркетинг та логістика в системі менеджменту». - Львів : Львівська політехніка, 2014 - С.364-366.

7. Тєлєтов О.С. Інновації в маркетингу промислових підприємств [монографія] / О.С. Тєлєтов, Н.В. Івашова, Є. І. Нагорний ; за заг. редакцією д-ра екон. наук. проф. О.С. Тєлєтова. - Суми : СумДУ, 2013. - 282 с.

8. Тєлєтов О.С. Маркетингова освіта в умовах реального сектора економіки / О.С. Тєлєтов //Економічний вісник НТТУ “КПІ". — 2014. — №11. - С. 435-439.

9. Закон України «Про вищу освіту» від 01.07.14 № 1556-VII. [Електронний ресурс]. Режим доступу : http://zakon2.rada.gov.ua/laws/show/1556-18.

10. Мельников С. Л. Управление высшим образованием в демократических государствах / С.Л. Мельников // Сумська старовина. - 2014. - № 41-42. - С. 61-66 .

11. Стратегія економічного розвитку України до 2020 року: стратегія національної модернізації. Міністерство економіки України [Електронний ресурс]. — Режим доступу:http://me.kmu.gov.ua. 